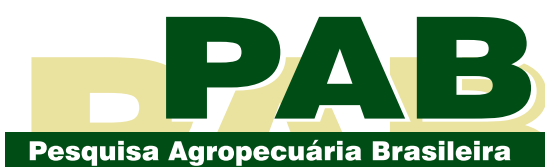

ISSN 1678-3921

Journal homepage: www.embrapa.br/pab

For manuscript submission and journal contents, access: www.scielo.br/pab

\title{
Forest restoration by different nucleation techniques in Urochloa grassland
}

\begin{abstract}
The objective of this work was to evaluate the effect of brushwood, black plastic mulch, herbicide, and artificial perch on the natural regeneration of native species in Urochloa grassland. The experiment was conducted between February 2014 and February 2016 in the Dense Ombrophilous Forest, in the municipality of Morretes, in the state of Paraná, Brazil. The treatments were: herbicide, herbicide + perch, black plastic mulch, black plastic mulch + perch, brushwood + herbicide, brushwood + herbicide + perch, and a control treatment. The evaluations were carried out at 4, 8, 12, 18, and 24 months after the installation of the experiment, by counting and identifying regenerating woody species and estimating visually the percentage of herbaceous coverage. Initially, brushwood and black plastic mulch reduced the Urochloa grasses; however, this effect was lost over time due to the rapid growth of the grasses from the edges to the center of the plots. The use of perches in the treatments does not allow a significant increase of other species because of the continued inhibiting conditions for the establishment of seedlings. The herbicide is effective in removing the grasses; however, the recruitment of woody species is only satisfactory when perches are used to attract the dispersing fauna. For a successful ecological restoration of pastures, there is a need for the local elimination of Urochloa grasses.
\end{abstract}

Index terms: artificial perch, black plastic mulch, brushwood, herbicide, natural regeneration.

\section{Restauração florestal por diferentes técnicas de nucleação em área com pastagem de Urochloa}

Resumo - O objetivo deste trabalho foi avaliar os métodos galharia, cobertura por plástico preto, herbicida e poleiro artificial na regeneração natural de espécies nativas em área com pastagem de Urochloa. O experimento foi conduzido entre fevereiro de 2014 e fevereiro de 2016 na Floresta Ombrófila Densa, no município de Morretes, no estado do Paraná, Brasil. Os tratamentos foram: herbicida, herbicida + poleiro, cobertura por plástico preto, cobertura por plástico preto + poleiro, galharia + herbicida, galharia + herbicida + poleiro e testemunha. As avaliações foram realizadas aos 4, 8, 12, 18 e 24 meses após a instalação do experimento, com contagem e identificação das espécies lenhosas regenerantes e estimativa visual do percentual de cobertura por herbáceas. Inicialmente, a galharia e a cobertura por plástico preto reduziram as gramíneas Urochloa; entretanto, com o decorrer do tempo, esse efeito se perdeu devido ao rápido crescimento das gramíneas das bordas para o centro das parcelas. $\mathrm{O}$ uso de poleiros nos tratamentos não possibilita incremento significativo de outras espécies, em razão da permanência das condições inibidoras ao estabelecimento das plântulas. O herbicida é eficiente para remover as gramíneas; contudo, o recrutamento de espécies lenhosas somente é satisfatório com o uso de poleiros para atração da fauna dispersora. 
Para o sucesso da restauração ecológica em pastagens, há a necessidade de eliminação local das gramíneas Urochloa.

Termos para indexação: poleiro artificial, cobertura por plástico preto, galharia, herbicida, regeneração natural.

\section{Introduction}

The conversion of forests to pasture for livestock is common in tropical landscapes, leading to unconnected habitats and serious damage to biodiversity (Sobanski \& Marques, 2014). The lack of planning in the occupation of lands destined for agricultural activities, associated with inadequate management practices, causes accelerated soil degradation, resulting in unproductive areas that end up being used as pasture (Elgar et al., 2014; Guidetti et al., 2016). For this reason, in Brazil, many actions to restore degraded ecosystems have been carried out in abandoned open areas or previous grazing pastures (Guerra et al., 2020).

Many pastures are formed by grasses of the genus Urochloa, which inhibits natural regeneration (Fragoso et al., 2017; Weidlich et al., 2020). In grasslands, seedling recruitment is reduced due to factors such as: competition for water, light, and nutrients; allelopathy; absence of dispersing fauna; predation; inadequate microclimate conditions; and physical and chemical soil degradation (Maza-Villalobos et al., 2011; Sobanski \& Marques, 2014).

Traditionally, forest restoration programs are executed by planting mixed stands of tree species and physically protecting the area (Chazdon \& Uriarte, 2016). In this phase, cultivation treatments, such as weeding, brushing, and herbicide application, are necessary, but rarely performed (Weidlich et al., 2020). Furthermore, in grazing areas that are solely protected and receive no cultivation treatments, natural regeneration (secondary succession) is slow or nonexistent (Bechara et al., 2016).

In this context, several restoration practices, which are still poorly applied or developed, focus on a set of processes that benefit species succession (Connell \& Slatyer, 1977). Nucleation, for example, seeks to induce natural regeneration from one point (the nucleus) that is different from the surrounding matrix, in order to attract seeds and/or favor their germination and development. For nucleus management, artificial perches and brushwood (Reis et al., 2014) are included in the area, while inhibitory vegetation is removed by using herbicides (Elgar et al., 2014) or black plastic mulch (Tomazi \& Castellani, 2016).

The use of artificial perches has been proposed to attract seed-dispersing birds, increasing seed rainfall (Reis et al., 2014). However, because it is important that the seeds deposited below the perches have adequate conditions to germinate and grow, seedbed improvement practices have also been suggested, without which the dispersed seeds would be unlikely to survive (Almeida et al., 2016; Tomazi \& Castellani, 2016).

Brushwood is a method of environmental complexation, which seeks to improve the quality of the seedbed and, consequently, to create an environment conducive to incoming seeds (Carpanezzi \& Nicodemo, 2009). This is possible because brushwood shading and gradual decomposition improve soil aspects, such as organic matter and microorganisms (Reis et al., 2014). In this method, inert plant residues, such as materials from trees, trunks, bamboos, and forest residues, are collected to form natural regeneration nuclei (Reis et al., 2014).

Herbicides and black plastic mulch are other methods used to prepare the seedbed, but by removing inhibitory vegetation (Elgar et al., 2014; Weidlich et al., 2020). When done correctly and other options are not feasible, the application of herbicides to control undesirable species is an effective and inexpensive restoration tool (Simberloff, 2014; Galindo et al., 2017). Black plastic mulch, developed as a method to control weeds, is commonly used in agriculture; in ecological restoration programs, it allows the creation of an environment favorable for the regeneration of native species by reducing inhibitory plants (Marushia \& Allen, 2011).

Since all these methods are simple and cheap to carry out, they have awoken much interest, which has been increased by the promise of a lower need for cultivation methods both during and after their implantation phase (Zahawi et al., 2013; Chazdon \& Uriarte, 2016). However, ecological restoration actions must take into account each environmental scenario, in order to provide technical recommendations that are adapted to the local reality and supported by field results (Holl et al., 2017).

The objective of this work was to evaluate the effectiveness of brushwood, black plastic mulch, herbicide, and artificial perch on the natural regeneration of native species in Urochloa grassland. 


\section{Materials and Methods}

The experiment was conducted between February 2014 and February 2016 at the experimental station of Embrapa Florestas, located in the municipality of Morretes, in the coastal region of the state of Paraná, Southern Brazil $\left(25^{\circ} 26^{\prime} 56^{\prime \prime} \mathrm{S}, 48^{\circ} 52^{\prime} 18^{\prime \prime} \mathrm{W}\right)$, in the phytoecological region known as lowland Atlantic rainforest, a Dense Ombrophilous Forest.

The relief was flat and the soil was classified as a Cambissolo Háplico $\mathrm{Tb}$ distrófico according to Brazilian soil classification system (Santos et al., 2018), i.e., a Dystric Cambisol according to FAO's World Reference Base for soils (IUSS Working Group WRB, 2015), with a moderate A horizon and clayey texture. According to Köppen's classification, the climate is $\mathrm{Cfa}$, humid subtropical, reaching average temperatures close to $17^{\circ} \mathrm{C}$ in the cooler months and to $24^{\circ} \mathrm{C}$ in the hottest ones, with infrequent frosts and trend of concentration of rainfall in the summer, but no defined dry season. The mean annual rainfall is between 2.000 and $2.200 \mathrm{~mm}$, and the average annual temperature is close to $21^{\circ} \mathrm{C}$.

Initially, the area was used for crops and later was converted to pasture with Urochloa humidicola (Rendle) Morrone \& Zuloaga as forage for buffalo breeding, being kept in this condition for about 15 years. Afterwards, the area was first abandoned for 10 years, when soil mechanization was performed using crawler bulldozers to remove vegetation, with the consequent partial decapitation of the A horizon, and then abandoned again for 2 years. During the pasture abandonment periods, the Urochloa subquadripara (Trin.) R.D.Webster and Urochloa decumbens (Stapf) R.D.Webster grasses invaded the area, becoming dominant. At the beginning of the experiment, the predominant vegetation was Urochloa, containing small patches of spontaneous herbs. The surrounding area was predominantly rural, with farms intended for livestock and agriculture, but, at approximately $500 \mathrm{~m}$ or less, there were also many natural forest fragments in different stages of succession, which can act as important sources of seeds for regeneration.

The experiment was established with 28 plots of $8 \times 5 \mathrm{~m}\left(40 \mathrm{~m}^{2}\right)$, corresponding to seven treatments and four replicates, organized in a randomized complete block design, totaling $1,120 \mathrm{~m}^{2}$. In all plots, except in the control treatment, first, mowing was performed with a backpack machine, leaving the residue on the soil. Then, the following treatments were applied: herbicide, herbicide + artificial perch; black plastic mulch; black plastic mulch + artificial perch; brushwood + herbicide; brushwood + herbicide + artificial perch; and a control, with no treatment application.

In the herbicide treatment, 15 days after mowing, $62.35 \mathrm{~g} \mathrm{ha}^{-1}$ haloxyfop-P-methyl, a selective herbicide of the aryloxyphenoxypropionic acid chemical group, were applied post-emergence to the plants in the entire area of the plot at a spray volume of $100 \mathrm{~L} \mathrm{ha}^{-1}$.

In the herbicide + perch treatment, in addition to herbicide application to the soil, an artificial perch was installed at the center of the plot. The perch was made of a treated eucalyptus pole, kept $4 \mathrm{~m}$ above the ground. Two sticks of $1 \mathrm{~m}$ in length were placed in the upper portion, arranged horizontally to the ground, crosswise, and spaced $40 \mathrm{~cm}$ apart and from the perch apex.

For the black plastic mulch treatment, a black plastic film with $100 \mu \mathrm{m}$ thickness was used to cover the total area of each plot for a period of 60 days.

The black plastic mulch + perch treatment was similar to the previous one, but an artificial perch was placed at the center of the plot after the plastic film was removed.

The brushwood + herbicide treatment involved arranging plant residues and then applying the post-emergent herbicide haloxyfop-P-methyl. The brushwood was formed by seven layers and reached a height of approximately $0.5 \mathrm{~m}$. The layers were arranged in the following order: small wood and peach palm logs, leafless bamboo sticks, wooden slabs and leafless bamboo sticks, palm leaves, leafless bamboo sticks, bamboo sticks with leaves, and palm leaves. Initially, the brushwood treatment did not include herbicide application; however, it was necessary due to the aggressive growth of the surrounding grasses 60 days after the treatment's installation, in order to reduce the reinvasion of the plots.

The brushwood + herbicide + perch treatment was similar to the previous one, but an artificial perch was placed at the center of the plot.

The treatments were evaluated at $4,8,12,18$, and 24 months after the installation of the experiment in February 2014. All individual shrubs and trees found were counted and identified. Woody species were classified according to: their origin, as native or exotic (Flora do Brasil 2020, 2020); seed dispersal syndromes, 
as zoochorous, anemochoric, or autochorous (Pijl, 1982); and successional categories, as pioneer, secondary, or climax (Budowski, 1965).

The percentage of herbaceous species covering the ground was estimated visually by sequentially placing a $0.50 \times 0.50 \mathrm{~m}$ quadrant over a $0.50 \times 5 \mathrm{~m}$ subplot, located at the center of the $8 \times 5 \mathrm{~m}$ plot, resulting in ten sampling points or quadrants. Three classes were considered: grasses (Poaceae family), other herbs, and lack of vegetation on the ground (bare soil). The percentage of grasses regrowing from the edges of the plots towards the center was calculated, being represented by quadrants (Q) from 1 to 5: Q1, mean of quadrants 1 and 2; Q2, mean of quadrants 3 and 4; Q3, mean of quadrants 5 and 6; Q4, mean of quadrants 7 and 8; and Q5, mean of quadrants 9 and 10. Q3 was at the center of the plot, and Q1 and Q5 at the edges. The present herbaceous species were identified and classified according to: their origin, as native or subspontaneous (ruderals, cosmopolitan, and exotic) (Flora do Brasil 2020, 2020); and dispersal syndromes, as zoochorous, anemochoric, or autochorous (Pijl, 1982).

The homogeneity of variances was evaluated by Bartlett's test and, subsequently, the data were subjected to the analysis of variance, in a split-plot design. The main plots corresponded to the seven treatments, and the subplots, to the five evaluation periods $(4,8,12$, 18 , and 24 months). When statistically significant, the averages of the studied variables were subjected to Tukey's test, at $5 \%$ probability.

\section{Results and Discussion}

At the end of the trial period, there were 2,175 woody plants in all treatments, distributed into five shrub species and 26 tree species (Table 1). Of the woody species found, 11 were not identified, as they were seedlings and difficult to classify. There were few shrub and tree species in all treatments, except in the herbicide + perch treatment (Table 1), which presented a higher number of tree species (21), compared with shrub species (5). The higher number of tree species in this treatment seems to be related to the effectiveness of the herbicide in controlling grasses at the base of the perch, together with the increased seed rain from the perches, leading to the establishment of native species (Elgar et al., 2014). This result is reinforced by the fact that all trees, except Sapium glandulosum (L.) Morong and Mimosa bimucronata (DC.) Kuntze, were restricted to the projection of the perch rods. Furthermore, most trees were located under the perch rods, confirming zoochory (in this case, ornithochory) as the main dispersal mechanism for these species (Table 1).

The greatest richness in woody species found in the plots subjected to the herbicide + perch treatment indicates how tools to attract seed dispersers are important in accelerating succession. However, although they can increase seed rain, artificial perches do not guarantee seedling establishment in areas without favorable conditions, as reported in other studies (Almeida et al., 2016; Tomazi \& Castellani, 2016). Therefore, the recruitment of new species in tropical pastures depends not only on seed dispersal, but also on actions that provide a higher seedbed quality (Fragoso et al., 2017). In the brushwood and black plastic mulch treatment, the absence of a seedbed favoring natural regeneration explains why the perch did not increase the number of individuals and the richness in woody species (Table 1). In the herbicide treatment without the artificial perch, both the formation of a seedbed that favored natural regeneration and the control of grasses led to a higher density of shrubs; however, the increase in the number of tree species was lower precisely due to the absence of the artificial perch.

It should be noted that about $85 \%$ of the tree species found in the plots with herbicide + perch only appeared after 18 months of evaluation, suggesting the time required to recruit trees. This is consistent with the findings of a previous study about the area's seed bank, which showed a low occurrence of shrub and tree plants (Fragoso et al., 2018). The absence of woody species is common in seed banks in abandoned pastures, as many species lack prolonged dormancy and their presence in the area is largely dependent on seedbed quality, especially since the large grass biomass in the soil hinders the incorporation of allogeneic propagules into the seed bank (Maza-Villalobos et al., 2011). Therefore, even when artificial perches were used, the natural regeneration of trees was slow and occurred well after the herbaceous and shrub layers were established, which seems to be related to the increased structural complexity in these plots (Zahawi et al., 2013). In addition, the high level of shading promoted 
Table 1. Naturally regenerated woody species after 24 months of evaluation in a Urochloa grassland in Southern Brazil ${ }^{(1)}$.

\begin{tabular}{|c|c|c|c|c|c|c|c|c|c|c|c|c|}
\hline Family/ species & NI & LF & OR & $\mathrm{SC}$ & SD & $\mathrm{H}$ & $\mathrm{H}+\mathrm{P}$ & $\mathrm{BP}$ & $\mathrm{BP}+\mathrm{P}$ & $\mathrm{B}+\mathrm{H}$ & $\mathrm{B}+\mathrm{H}+\mathrm{P}$ & $\mathrm{C}$ \\
\hline ARECACEAE & 20 & & & & & & & & & & & \\
\hline Euterpe edulis Mart. & 20 & Tree & Nat & $\mathrm{Cl}$ & Zoo & 0 & 20 & 0 & 0 & 0 & 0 & 0 \\
\hline ASTERACEAE & 1,711 & & & & & & & & & & & \\
\hline $\begin{array}{l}\text { Chromolaena maximilianii } \\
\text { (Schrad. ex DC.) R.M.King \& H.Rob. }\end{array}$ & 138 & Shrub & Nat & $\mathrm{Pi}$ & Ane & 80 & 41 & 10 & 3 & 0 & 2 & 2 \\
\hline Vernonanthura beyrichii (Less.) H.Rob. & 1,573 & Shrub & Nat & $\mathrm{Pi}$ & Ane & 464 & 691 & 11 & 9 & 66 & 224 & 108 \\
\hline ELAEOCARPACEAE & 2 & & & & & & & & & & & \\
\hline Sloanea guianensis Benth. & 2 & Tree & Nat & $\mathrm{Se}$ & Zoo & 0 & 2 & 0 & 0 & 0 & 0 & 0 \\
\hline EUPHORBIACEAE & 3 & & & & & & & & & & & \\
\hline $\begin{array}{l}\text { Alchornea triplinervia } \\
\text { (Spreng.) Müll.Arg. }\end{array}$ & 1 & Tree & Nat & $\mathrm{Se}$ & Zoo & 0 & 1 & 0 & 0 & 0 & 0 & 0 \\
\hline Sapium glandulosum (L.) Morong & 2 & Tree & Nat & $\mathrm{Se}$ & Zoo & 0 & 2 & 0 & 0 & 0 & 0 & 0 \\
\hline FABACEAE & 17 & & & & & & & & & & & \\
\hline Mimosa bimucronata (DC.) Kuntze & 17 & Tree & Nat & $\mathrm{Pi}$ & Aut & 4 & 3 & 0 & 1 & 2 & 3 & 4 \\
\hline LAURACEAE & 11 & & & & & & & & & & & \\
\hline Lauraceae 1 & 11 & Tree & $\mathrm{nc}$ & $\mathrm{nc}$ & $\mathrm{nc}$ & 0 & 9 & 2 & 0 & 0 & 0 & 0 \\
\hline MELIACEAE & 1 & & & & & & & & & & & \\
\hline Trichilia elegans A.Juss. & 1 & Tree & Nat & $\mathrm{Se}$ & Zoo & 0 & 1 & 0 & 0 & 0 & 0 & 0 \\
\hline MYRSINACEAE & 11 & & & & & & & & & & & \\
\hline Myrsine coriacea (Sw.) R.Br. & 11 & Tree & Nat & $\mathrm{Se}$ & Zoo & 1 & 6 & 4 & 0 & 0 & 0 & 0 \\
\hline MYRTACEAE & 4 & & & & & & & & & & & \\
\hline Marlierea tomentosa Cambess. & 1 & Tree & Nat & $\mathrm{Se}$ & Zoo & 0 & 1 & 0 & 0 & 0 & 0 & 0 \\
\hline Myrtaceae 1 & 1 & Tree & $\mathrm{nc}$ & $\mathrm{nc}$ & $\mathrm{nc}$ & 0 & 1 & 0 & 0 & 0 & 0 & 0 \\
\hline Myrtaceae 2 & 1 & Tree & $\mathrm{nc}$ & $\mathrm{nc}$ & $\mathrm{nc}$ & 0 & 1 & 0 & 0 & 0 & 0 & 0 \\
\hline Myrtaceae 3 & 1 & Tree & $\mathrm{nc}$ & $\mathrm{nc}$ & $\mathrm{nc}$ & 0 & 1 & 0 & 0 & 0 & 0 & 0 \\
\hline ONAGRACEAE & 88 & & & & & & & & & & & \\
\hline Ludwigia octovalvis (Jacq.) P.H.Raven & 88 & Shrub & Nat & $\mathrm{Pi}$ & Ane & 80 & 2 & 0 & 2 & 0 & 0 & 4 \\
\hline SALICACEAE & 35 & & & & & & & & & & & \\
\hline Casearia decandra Jacq. & 35 & Tree & Nat & $\mathrm{Se}$ & Zoo & 0 & 35 & 0 & 0 & 0 & 0 & 0 \\
\hline SOLANACEAE & 8 & & & & & & & & & & & \\
\hline Acnistus arborescens (L.) Schltdl. & 8 & Shrub & Nat & $\mathrm{Pi}$ & Zoo & 1 & 3 & 4 & 0 & 0 & 0 & 0 \\
\hline VERBENACEAE & 243 & & & & & & & & & & & \\
\hline Stachytarpheta cayennensis (Rich.) Vahl & 232 & Shrub & Sub & Pi & Aut & 26 & 152 & 21 & 0 & 4 & 11 & 18 \\
\hline Citharexylum myrianthum Cham. & 11 & Tree & Nat & $\mathrm{Se}$ & Zoo & 3 & 6 & 0 & 0 & 1 & 0 & 1 \\
\hline Undetermined species ${ }^{(2)}$ & 21 & & & & & & & & & & & \\
\hline Undetermined 1 & 7 & Tree & $\mathrm{nc}$ & $\mathrm{nc}$ & $\mathrm{nc}$ & 0 & 7 & 0 & 0 & 0 & 0 & 0 \\
\hline Undetermined 2 & 1 & Tree & $\mathrm{nc}$ & $\mathrm{nc}$ & $\mathrm{nc}$ & 0 & 1 & 0 & 0 & 0 & 0 & 0 \\
\hline Undetermined 3 & 1 & Tree & $\mathrm{nc}$ & $\mathrm{nc}$ & $\mathrm{nc}$ & 0 & 1 & 0 & 0 & 0 & 0 & 0 \\
\hline Undetermined 4 & 7 & Tree & $\mathrm{nc}$ & $\mathrm{nc}$ & $\mathrm{nc}$ & 1 & 6 & 0 & 0 & 0 & 0 & 0 \\
\hline Undetermined 5 & 2 & Tree & $\mathrm{nc}$ & $\mathrm{nc}$ & $\mathrm{nc}$ & 0 & 2 & 0 & 0 & 0 & 0 & 0 \\
\hline Undetermined 6 & 2 & Tree & $\mathrm{nc}$ & $\mathrm{nc}$ & $\mathrm{nc}$ & 0 & 2 & 0 & 0 & 0 & 0 & 0 \\
\hline Undetermined 7 & 1 & Tree & $\mathrm{nc}$ & $\mathrm{nc}$ & $\mathrm{nc}$ & 0 & 1 & 0 & 0 & 0 & 0 & 0 \\
\hline Total NI & 2,175 & & & & & 660 & 998 & 52 & 15 & 73 & 240 & 137 \\
\hline Total species & 26 & & & & & 9 & 26 & 6 & 4 & 4 & 4 & 6 \\
\hline
\end{tabular}

(1)NI, total number of individuals; LF, life form; OR, origin; SC, successional category; SD, seed dispersal syndromes; Nat, native; Cl, climax; Zoo, zoochorous; Pi, pioneer; Ane, anemochoric; Se, secondary; Aut, autochorous; and nc, not classified. ${ }^{(2)}$ Woody species not identified, as they were in seedling stage. Treatments: $\mathrm{H}$, herbicide; $\mathrm{H}+\mathrm{P}$, herbicide + perch; BP, black plastic mulch; $\mathrm{BP}+\mathrm{P}$, black plastic mulch + perch; $\mathrm{B}+\mathrm{H}$, brushwood + herbicide; $\mathrm{B}+\mathrm{H}+\mathrm{P}$, brushwood + herbicide + perch; and $\mathrm{C}$, control. 
by the shrubs may have reflected in the category of the successional species found (Table 1), favoring trees of intermediate and late categories that can regenerate even under low light levels (Galindo et al., 2017).

According to the analysis of variance, there were significant interactions between all treatments and evaluation periods $(4,8,12,18$, and 24 months), indicating that they are not independent (Table 2). The highest density of woody plants was observed in the herbicide and in the herbicide + perch treatments, especially at 18 (5.23 woody plants per square meter) and 24 (6.24 woody plants per square meter) months, respectively. The brushwood and black plastic mulch treatments with and without the perch had a few woody plants, even when compared with the control, supporting the idea that there are barriers to seedling recruitment (Elgar et al., 2014). Only in the herbicide treatments with and without the perch was the density of woody species compatible with that found in areas without vegetation inhibiting natural regeneration (Marcuzzo et al., 2013; Cruz et al., 2020). In the other treatments, there were no suitable sites for seed germination and seedling establishment due to the continued presence of grasses (Galindo et al., 2017); therefore, the natural regeneration of woody species was rather slow or absent, despite nearby forest remnants (Fragoso et al., 2017).

The higher density of woody species observed in the herbicide treatments can be understood as a result of the dynamics of the colonization by non-forage plants (Maçaneiro et al., 2017). The presence of other life forms, and not only of woody plants, is important for the resumption of natural regeneration processes in these areas and can help control invasive grasses (MazaVillalobos et al., 2011). Herbaceous and sub-shrub species start flowering and fruiting early, which make up the main elements of the first stages of succession. These species are also highlighted in nucleation methods as facilitators of natural regeneration that significantly improve environmental conditions and, consequently, enable the emergence of other more demanding species (Piaia et al., 2017). Therefore, the obtained results are indicative that the effective control of grasses, by the application of a selective herbicide, allows for the establishment of herbaceous plants with a rapid growth and broad coverage, especially of Desmodium triflorum (L.) DC. and Sphagneticola trilobata (L.) Pruski, which were the spontaneous herbs found at the highest percentages in the herbicide plots at 12 and 18 months (Table 3). Many of the herbaceous species identified in the present study were raised in the seed bank (Fragoso et al., 2018). The entry of light caused by the removal of grasses stimulated the germination of the seeds contained in the seed bank, which increased the predominance of species with abiotic dispersion syndromes (72\%), e.g., anemochory and autochory, and contributed to their continued presence in the herbicide plots. This is attributed to the fact that colonizing herbaceous plants are highly dependent on light to germinate and may remain dormant in the soil for long periods (Maza-Villalobos et al., 2011). Other very common herbaceous plants

Table 2. Woody species per square meter during the evaluation periods in a Urochloa grassland in Southern Brazil ${ }^{(1)}$.

\begin{tabular}{|c|c|c|c|c|c|c|}
\hline \multirow[t]{2}{*}{ Treatment $^{(2)}$} & \multicolumn{6}{|c|}{ Tree and shrub } \\
\hline & 4 months & 8 months & 12 months & 18 months & 24 months & Average \\
\hline $\mathrm{H}$ & $0.00 \mathrm{aC}$ & $3.63 \mathrm{aB}$ & $4.64 \mathrm{aAB}$ & $5.23 \mathrm{aA}$ & $4.13 \mathrm{aAB}$ & 3.53 \\
\hline $\mathrm{H}+\mathrm{P}$ & $0.00 \mathrm{aC}$ & $4.55 \mathrm{aB}$ & $4.32 \mathrm{aB}$ & $3.88 \mathrm{aB}$ & $6.24 \mathrm{aA}$ & 3.80 \\
\hline $\mathrm{BP}$ & $0.06 \mathrm{aA}$ & $0.36 \mathrm{bA}$ & $0.29 \mathrm{bA}$ & $0.24 \mathrm{bA}$ & $0.36 \mathrm{bA}$ & 0.26 \\
\hline $\mathrm{BP}+\mathrm{P}$ & $0.01 \mathrm{aA}$ & $0.04 \mathrm{bA}$ & $0.09 \mathrm{bA}$ & $0.09 \mathrm{bA}$ & $0.09 \mathrm{bA}$ & 0.07 \\
\hline $\mathrm{B}+\mathrm{H}$ & $0.00 \mathrm{aA}$ & $0.58 \mathrm{bA}$ & $0.89 \mathrm{bA}$ & $0.39 \mathrm{bA}$ & $0.48 \mathrm{bA}$ & 0.47 \\
\hline $\mathrm{B}+\mathrm{H}+\mathrm{P}$ & $0.01 \mathrm{aB}$ & $1.08 \mathrm{bAB}$ & $2.13 \mathrm{abA}$ & $0.85 \mathrm{bAB}$ & $1.50 \mathrm{bAB}$ & 1.11 \\
\hline $\mathrm{C}$ & $0.06 \mathrm{aA}$ & $1.03 \mathrm{bA}$ & $1.15 \mathrm{bA}$ & $0.38 \mathrm{bA}$ & $0.86 \mathrm{bA}$ & 0.69 \\
\hline Average & 0.02 & 1.61 & 1.93 & 1.58 & 1.95 & \\
\hline \multicolumn{7}{|c|}{$\mathrm{CV}(\mathrm{a})=143.92 \% \quad / \quad \mathrm{CV}(\mathrm{b})=55.50 \%$} \\
\hline
\end{tabular}


observed in the experimental area were: Kyllinga brevifolia Rottb., Cyperus mundtii (Nees) Kunth, Scleria melaleuca C.B.Clarke, Mikania micrantha Kunth, Commelina diffusa Burm.f., and Melothria pendula L. In total, 53 non-forage herbaceous species were identified, the majority of which were native (94\%), belonging to 25 families, with Asteraceae and Cyperaceae presenting the highest species richness.
These families are frequently found in open areas, such as abandoned pastures, which is attributed to their successful colonization in degraded environments and to the formation of a persistent seed bank (Fragoso et al., 2018). Once established, herbaceous plants efficiently prevented surrounding grasses from entering the herbicide plots, favoring the establishment of shrub species, such as Vernonanthura beyrichii

Table 3. Percentage of grass (Poaceae) coverage, spontaneous herbs, and lack of vegetation on the ground (bare soil) throughout the evaluations in a Urochloa grassland in Southern Brazil ${ }^{(1)}$.

\begin{tabular}{|c|c|c|c|c|c|c|}
\hline \multirow[t]{2}{*}{ Treatment ${ }^{(2)}$} & \multicolumn{6}{|c|}{ Period of evaluation } \\
\hline & 4 months & 8 months & 12 months & 18 months & 24 months & Average \\
\hline & \multicolumn{6}{|c|}{ Grasses (\%) } \\
\hline $\mathrm{H}$ & $0.00 \mathrm{bB}$ & $0.00 \mathrm{cB}$ & $4.88 \mathrm{cB}$ & $7.13 \mathrm{cB}$ & $33.75 \mathrm{bcA}$ & 9.15 \\
\hline $\mathrm{H}+\mathrm{P}$ & $5.50 \mathrm{bA}$ & $0.50 \mathrm{bcA}$ & $8.38 \mathrm{bcA}$ & $17.00 \mathrm{bcA}$ & $23.00 \mathrm{cA}$ & 10.88 \\
\hline $\mathrm{BP}$ & $19.00 \mathrm{bB}$ & $39.00 \mathrm{abB}$ & $82.63 \mathrm{aA}$ & $80.88 \mathrm{aA}$ & $84.13 \mathrm{aA}$ & 61.13 \\
\hline $\mathrm{BP}+\mathrm{P}$ & $13.63 \mathrm{bB}$ & $22.75 \mathrm{bcB}$ & $67.13 \mathrm{aA}$ & $65.00 \mathrm{aA}$ & $83.13 \mathrm{aA}$ & 50.33 \\
\hline $\mathrm{B}+\mathrm{H}$ & $5.50 \mathrm{bB}$ & $23.00 \mathrm{bcB}$ & $53.50 \mathrm{aA}$ & $61.50 \mathrm{aA}$ & $72.75 \mathrm{aA}$ & 43.25 \\
\hline $\mathrm{B}+\mathrm{H}+\mathrm{P}$ & $3.63 \mathrm{bB}$ & $5.50 \mathrm{bcB}$ & $44.50 \mathrm{abA}$ & $53.50 \mathrm{abA}$ & $66.25 \mathrm{abA}$ & 34.68 \\
\hline $\mathrm{C}$ & $68.45 \mathrm{aA}$ & $69.50 \mathrm{aA}$ & $83.13 \mathrm{aA}$ & $85.50 \mathrm{aA}$ & $88.50 \mathrm{aA}$ & 79.02 \\
\hline Average & 16.53 & 22.89 & 49.16 & 52.93 & 64.50 & \\
\hline \multicolumn{7}{|c|}{$\mathrm{CV}(\mathrm{a})=74.91 \% \quad / \quad \mathrm{CV}(\mathrm{b})=30.39 \%$} \\
\hline & \multicolumn{6}{|c|}{ Spontaneous herbs $(\%)$} \\
\hline $\mathrm{H}$ & $99.13 \mathrm{aA}$ & $99.13 \mathrm{aA}$ & $92.75 \mathrm{aA}$ & $92.13 \mathrm{aA}$ & $53.38 \mathrm{aB}$ & 87.30 \\
\hline $\mathrm{H}+\mathrm{P}$ & $87.50 \mathrm{abA}$ & $94.75 \mathrm{aA}$ & $89.88 \mathrm{aA}$ & $81.88 \mathrm{aA}$ & $49.25 \mathrm{abB}$ & 80.65 \\
\hline $\mathrm{BP}$ & $51.88 \mathrm{bcA}$ & $41.00 \mathrm{bcAB}$ & $17.25 \mathrm{bBC}$ & $19.13 \mathrm{bBC}$ & $15.75 \mathrm{bcC}$ & 29.00 \\
\hline $\mathrm{BP}+\mathrm{P}$ & $69.00 \mathrm{abA}$ & $67.63 \mathrm{abA}$ & $32.75 \mathrm{bB}$ & $35.00 \mathrm{bB}$ & $16.88 \mathrm{abcB}$ & 44.25 \\
\hline $\mathrm{B}+\mathrm{H}$ & $63.25 \mathrm{abcA}$ & $62.75 \mathrm{abcA}$ & $44.00 \mathrm{bAB}$ & $29.25 \mathrm{bB}$ & $26,5 \mathrm{abcB}$ & 45.15 \\
\hline $\mathrm{B}+\mathrm{H}+\mathrm{P}$ & $79.00 \mathrm{abA}$ & $69.88 \mathrm{abA}$ & $41.75 \mathrm{bB}$ & $42.75 b B$ & $26.13 \mathrm{abcB}$ & 51,90 \\
\hline $\mathrm{C}$ & $26.55 \mathrm{cA}$ & $27.13 \mathrm{cA}$ & $16.88 \mathrm{bA}$ & $14.00 \mathrm{bA}$ & $11.25 \mathrm{cA}$ & 19.16 \\
\hline Average & 68.04 & 66.04 & 47.89 & 44.88 & 28.45 & \\
\hline \multicolumn{7}{|c|}{$\mathrm{CV}(\mathrm{a})=56.98 \% \quad / \quad \mathrm{CV}(\mathrm{b})=23.65 \%$} \\
\hline & \multicolumn{6}{|c|}{ Lack of vegetation on the ground (\%) } \\
\hline $\mathrm{H}$ & $0.88 \mathrm{bA}$ & $0.88 \mathrm{cA}$ & $2.38 \mathrm{aA}$ & $0.75 \mathrm{aA}$ & $12.88 \mathrm{aA}$ & 3.55 \\
\hline $\mathrm{H}+\mathrm{P}$ & $7.00 \mathrm{bB}$ & $4.75 \mathrm{bcB}$ & $1.75 \mathrm{aB}$ & $1.25 \mathrm{aB}$ & $27.75 \mathrm{aA}$ & 8.50 \\
\hline BP & $29.13 \mathrm{aA}$ & $19.88 \mathrm{abA}$ & $0.13 \mathrm{aB}$ & $0.00 \mathrm{aB}$ & $0.00 \mathrm{bB}$ & 9.83 \\
\hline $\mathrm{BP}+\mathrm{P}$ & $17.50 \mathrm{abA}$ & $9.63 \mathrm{abcAB}$ & $0.13 \mathrm{aB}$ & $0.00 \mathrm{aB}$ & $0.00 \mathrm{bB}$ & 5.45 \\
\hline $\mathrm{B}+\mathrm{H}$ & $31.25 \mathrm{aA}$ & $14.25 \mathrm{abcB}$ & $2.50 \mathrm{aB}$ & $9.25 \mathrm{aB}$ & $0.88 \mathrm{bB}$ & 11.63 \\
\hline $\mathrm{B}+\mathrm{H}+\mathrm{P}$ & 17.38abAB & $24.63 \mathrm{aA}$ & $13.75 \mathrm{aAB}$ & $3.50 \mathrm{aB}$ & $7.63 \mathrm{bB}$ & 13.38 \\
\hline $\mathrm{C}$ & $5.00 \mathrm{bA}$ & $3.38 \mathrm{bcA}$ & $0.00 \mathrm{aA}$ & $0.00 \mathrm{aA}$ & $0.25 \mathrm{bA}$ & 1.73 \\
\hline Average & 15.45 & 11.05 & 2.95 & 2.11 & 7.05 & \\
\hline $\mathrm{CV}(\mathrm{a})=144$ & & & & & & \\
\hline
\end{tabular}


(Less.) H.Rob. (Table 1), and triggering a successional process. At 24 months, there was a reduction in the percentage of spontaneous herbs in the herbicide plots with and without the perch (Table 3), which was possibly due to the shading caused by the increased density of $V$. beyrichii and the greater accumulation of litter on the ground (Galindo et al., 2017).

The $V$. beyrichii shrub presented the highest density in all treatments, including the control, representing about $70 \%$ of the woody species, among which it was one of the first to establish (Table 1). The species is described, in the Atlantic Forest, as a colonizing plant and is common in the natural regeneration of abandoned pastures (Scheer et al., 2011). Therefore, it was also present in initial natural regeneration areas near the experiment, forming groups about 2.5 $\mathrm{m}$ tall. Furthermore, the shrub established itself at high densities, especially in the plots with herbicide treatments, and could be responsible for maintaining the low percentage of pasture reinvasion verified in the reoccupation analysis of the plots (Figure 1) due to the shade it produced, which consequently weakened the grasses. Considering the importance of this shrub for regeneration in pastures and the results obtained in the herbicide treatments, the selective favoring of $V$. beyrichii could facilitate the establishment of other species, as has been shown in studies about the facilitating effect of pioneer shrubs in areas dominated by aggressive grasses (Medeiros et al., 2014; Galindo et al., 2017). The concept of facilitating plants is included in a set of mechanisms that act on plant communities, contributing to the direction of natural succession (Connell \& Slatyer, 1977). In this case, succession results, in part, from the changes in the environment caused by dominant colonizers in the initial phases (Maçaneiro et al., 2017), which is compatible with the results obtained in the present study for $V$. beyrichii and may have reflected in the establishment of the tree species found in the herbicide + perch plots.

Therefore, the successional dynamics promoted by the herbicide + artificial perch treatment could have allowed for a higher density and richness of woody species (Tables 1 and 2). This process is particularly useful when there are remnant forests nearby that act as seed sources, as in the study area, promoting the combined action of seed rain and a favorable seedbed for species germination and growth (Cruz et al., 2020). Other studies in areas dominated by aggressive growth grasses confirm the hypothesis that improving the seedbed by controlling inhibitory vegetation increases woody species in nucleation plots (Zahawi et al., 2013; Elgar et al., 2014).

In the brushwood treatments, with and without the perch, the subsequent herbicide application was less efficient in controlling the reinvasion of Urochloa grasses, as observed in the plot reoccupation analysis (Figure 1). As previously explained, this treatment initially did not include herbicide use, which became necessary to reduce the reinvasion in the plots caused by the aggressive growth of surrounding grasses 60 days after the installation of the treatment. The absence of inhibitory grasses generates positive results for the establishment of natural regeneration (Cruz et al., 2020), which was not the case in the present work, since pasture was a limiting factor for the success of the brushwood treatment. At first, the brushwood would kill the grasses due to the initial shading it provided, allowing the development of woody species seedlings as it began decomposing and gradually letting light reach the soil (Marcuzzo et al., 2013). However, the initial shading of the soil did not prevent the grasses from growing, as the dominant forage, U. subquadripara, spreads mainly by vegetative growth. Therefore, there was no longer a distinction between the edges $(\mathrm{Q} 1$ and Q5) and the center (Q3) of the plots after 12 months (Figure 1). Likewise, the subsequent application of the herbicide on the brushwood did not effectively prevent grasses from advancing, which hindered the establishment of woody species. Since herbicides are primarily absorbed by leaves, the most sensitive stage for their application on grasses is that of four to six leaves, making the control of larger plants less efficient (Pereira et al., 2018). Therefore, in abandoned pastures, in addition to brushwood (Reis et al., 2014), the herbicide should be applied at the base and around the nuclei to favor recovery through natural regeneration. It should be pointed out that the $40 \mathrm{~m}^{2}$ experimental plots were inefficient, even though they were larger than those of $1-12 \mathrm{~m}^{2}$ usually used in nucleation experiments in Brazil (Bechara et al., 2016). These result agree with those of another study that was carried out in an area with inhibitory vegetation, which showed that, for the recruitment of woody plants, the minimum nuclei size necessary is of $100 \mathrm{~m}^{2}$ (Zahawi et al., 2013). 

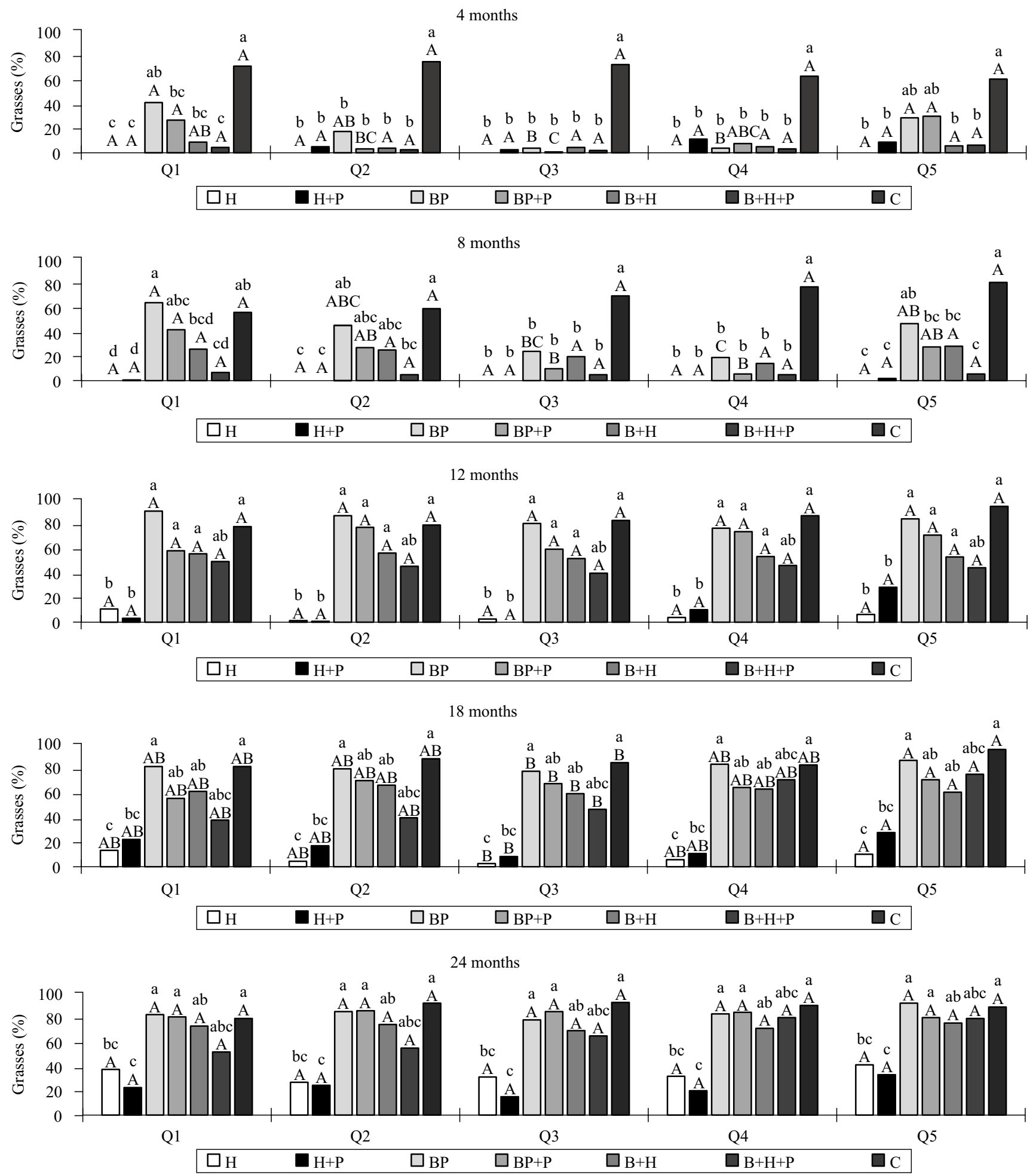

Figure 1. Percentage of coverage by grasses (Poaceae), throughout the evaluation periods, from the edges of the plots towards the center, according to quadrants $(\mathrm{Q}) 1$ to 5, with Q3 being the central one. Treatments: $\mathrm{H}$, herbicide; $\mathrm{H}+\mathrm{P}$, herbicide + perch; BP, black plastic mulch; BP+P, black plastic mulch + perch; B+H, brushwood + herbicide; $\mathrm{B}+\mathrm{H}+\mathrm{P}$, brushwood + herbicide + perch; and C, control. Means followed by equal lowercase letters do not differ between treatments within each quadrant, and means followed by equal uppercase letters do not differ between quadrants for each treatment by Tukey's test, at $5 \%$ probability. 
In the black plastic mulch treatments, despite the significant reduction in the biomass of inhibitory vegetation up to 8 months (Table 3), other herb species were also weakened due to the cessation of photosynthesis. This happened because, after the plastic film was removed, Urochloa grasses from the edges of the plots quickly covered the area, preventing other herbaceous species from recovering. This is supported by the analysis that showed the reoccupation of the plots by grasses (Figure 1), revealing that this phenomenon was faster in mulch treatments, both with and without the perch, with differences between the edges (Q1 and Q5) and center (Q3) of the plots only up to 8 months. In addition, since the first evaluation, the percentage of grasses at the plot edges did not differ from those of the control treatment. In another study (Tomazi \& Castellani, 2016), the application of black plastic film in an abandoned pasture presented few lasting effects due to the rapid reoccupation of the dominant grasses, confirming the need for the periodic management of the surrounding areas of mulch plots.

Similar results have been observed for persistent inhibitory grasses in the ecological recovery of pastures through other nucleation techniques (Vogel et al., 2015; Gerber et al., 2017). Therefore, early-stage cultural treatments are necessary for grass control and other purposes, suggesting that, despite the initial growth of woody species, the short periods evaluated in these studies may not reflect long-term results or extra-experimental conditions. The herbicide treatment associated with the perch was the one that facilitated the most the initial regeneration in the pasture. In the brushwood and black plastic mulch treatments, the seedbed did not improve and, therefore, the combined use of the artificial perch did not result in a greater establishment of natural regeneration. This shows that, after the removal of inhibiting vegetation, positive interactions are important for forest restructuring in degraded environments. Moreover, the positive effect of the artificial perch in attracting seed dispersers suggests that, besides the environmental restrictions imposed by grasses, additional factors, such as propagule availability, act synergistically in the presence of pastures (Elgar et al., 2014; Iguatemy et al., 2020).

\section{Conclusions}

1. The recruitment of the natural regeneration of woody plant species requires the local elimination of grasses of the Urochloa genus.

2. Initially, brushwood and black plastic mulch reduce grasses of the Urochloa genus, but, over time, their effects are no longer significant, hindering the recovery of native vegetation.

3. In the brushwood and black plastic mulch treatments, the combined use of artificial perches does not allow a significant growth of shrub and tree plants due to the lack of a favorable seedbed.

4. Although the applied herbicide is effective in removing grasses, the recruitment of woody species is only satisfactory when perches are used to attract the disperser fauna.

\section{Acknowledgments}

To Embrapa Florestas, to the Postgraduate Program in Agronomy - Plant Production of Universidade Federal do Paraná (UFPR), and to Coordenação de Aperfeiçoamento de Pessoal de Nível Superior (Capes), for support.

\section{References}

ALMEIDA, A. de; MARQUES, M.C.M.; CECCON-VALENTE, M. de F.; VICENTE-SILVA, J.; MIKICH, S.B. Limited effectiveness of artificial bird perches for the establishment of seedlings and the restoration of Brazil's Atlantic Forest. Journal for Nature Conservation, v.34, p.24-32, 2016. DOI: https://doi.org/10.1016/j.jnc.2016.08.007.

BECHARA, F.C.; DICKENS, S.J.; FARRER, E.C.; LARIOS, L.; SPOTSWOOD, E.N.; MARIOTTE, P.; SUDING, K.N. Neotropical rainforest restoration: comparing passive, plantation and nucleation approaches. Biodiversity and Conservation, v.25, p.2021-2034, 2016. DOI: https://doi.org/10.1007/s10531-016-11867.

BUDOWSKI, G. Distribution of tropical American rain forest species in the light of successional processes. Turrialba, v.15, p.40-42, 1965.

CARPANEZZI, A.A.; NICODEMO, M.L.F. (Ed.). Recuperação de mata ciliar e reserva legal florestal no noroeste paulista. São Carlos: Embrapa Pecuária Sudeste, 2009. 35p. (Embrapa Pecuária Sudeste. Documentos, 95; Embrapa Florestas, 188).

CHAZDON, R.L.; URIARTE, M. Natural regeneration in the context of large-scale forest and landscape restoration in the tropics. Biotropica, v.48, p.709-715, 2016. DOI: https://doi.org/10.1111/btp.12409. 
CONNELL, J.H.; SLATYER, R.O. Mechanisms of succession in natural communities and their role in community stability and organization. The American Naturalist, v.111, p.1119-1144, 1977. DOI: https://doi.org/10.1086/283241.

CRUZ, D.C. da; BENAYAS, J.M.R.; FERREIRA, G.C.; RIBEIRO, S.S. Tree communities in three-year-old post-mining sites under different forest restoration techniques in the Brazilian Amazon. Forests, v.11, art.527, 2020. DOI: https://doi.org/10.3390/ f11050527.

ELGAR, A.T.; FREEBODY, K.; POHLMAN, C.L.; SHOO, L.P.; CATTERALL, C.P. Overcoming barriers to seedling regeneration during forest restoration on tropical pasture land and the potential value of woody weeds. Frontiers in Plant Science, v.5, art.200, 2014. DOI: https://doi.org/10.3389/fpls.2014.00200.

FLORA DO BRASIL 2020. Available at: <http://floradobrasil. jbrj.gov.br/reflora/listaBrasil/ConsultaPublicaUC/ ConsultaPublicaUC.do\#CondicaoTaxonCP $>$. Accessed on: June 82020.

FRAGOSO, R. de O.; CARPANEZZI, A.A.; KOEHLER, H.S.; ZUFFELLATO-RIBAS, K.C. Barreiras ao estabelecimento da regeneração natural em áreas de pastagens abandonadas. Ciência Florestal, v.27, p.1451-1464, 2017. DOI: https://doi.org/10.5902/1980509830331.

FRAGOSO, R. de O.; CARPANEZZI, A.A.; ZUFFELLATORIBAS, K.C.; KOEHLER, H.S. Seed bank from abandoned pastures in the coastal region of Paraná. Floresta e Ambiente, v.25, e20150295, 2018. DOI: https://doi.org/10.1590/21798087.029515 .

GALINDO, V.; CALLE, Z.; CHARÁ, J.; ARMBRECHT, I. Facilitation by pioneer shrubs for the ecological restoration of riparian forests in the Central Andes of Colombia. Restoration Ecology, v.25, p.731-737, 2017. DOI: https://doi.org/10.1111/ rec. 12490 .

GERBER, D.; KIWARA, T.Y.; SOUZA, P.R. de; LUBKE, M.; VISMARA, E. de S.; BECHARA, F.C. Canopy cover and invasive grasses effects in distinct ecological restoration technologies: 5-y monitoring in a Brazilian subtropical forest. Acta Biológica Catarinense, v.4, p.54-59, 2017. DOI: https://doi.org/10.21726/ abc.v4i2.404.

GUERRA, A.; REIS, L.K.; BORGES, F.L.G.; OJEDA, P.T.A.; PINEDA, D.A.M.; MIRANDA, C.O.; MAIDANA, D.P.F. de L.; SANTOS, T.M.R. dos; SHIBUYA, P.S.; MARQUES, M.C.M.; LAURANCE, S.G.W.; GARCIA, L.C. Ecological restoration in Brazilian biomes: identifying advances and gaps. Forest Ecology and Management, v.458, art.117802, 2020. DOI: https://doi.org/10.1016/j.foreco.2019.117802.

GUIDETTI, B.Y.; AMICO, G.C.; DARDANELLI, S.; RODRIGUEZ-CABAL, M.A. Artificial perches promote vegetation restoration. Plant Ecology, v.217, p.935-942, 2016. DOI: https://doi.org/10.1007/s11258-016-0619-4.

HOLL, K.D.; REID, J.L.; CHAVES-FALLAS, J.M.; OVIEDOBRENES, F.; ZAHAWI, R.A. Local tropical forest restoration strategies affect tree recruitment more strongly than does landscape forest cover. Journal of Applied Ecology, v.54, p.10911099, 2017. DOI: https://doi.org/10.1111/1365-2664.12814.
IGUATEMY, M. de A.; VILARINHOS, J.A.; ODA, G.A.M.; CONDE, M. de M.S.; ZAÚ, A.S. Artificial perches: ecological and functional aspects of its contribution in the Atlantic Forest. Floresta e Ambiente, v.27, e20180301, 2020. DOI: https://doi.org/10.1590/2179-8087.030118.

IUSS WORKING GROUP WRB. World Reference Base for Soil Resources 2014: international soil classification system for naming soils and creating legends for soil maps: update 2015. Rome: FAO, 2015. (FAO. World Soil Resources Reports, 106).

MAÇANEIRO, J.P.; GASPER, A.L.; SCHORN, L.A.; GALVÃO, F. Few dominant native woody species: how subtropical rainforest successional process acts on abandoned pastures in Southern Brazil. Applied Ecology and Environmental Research, v.15, p.1633-1676, 2017. DOI: https://doi.org/10.15666/ aeer/1504_16331676.

MARCUZZO, S.B.; GANADE, G.; ARAÚJO, M.M.; MUNIZ, M.F.B. Comparação da eficácia de técnicas de nucleação para restauração de área degradada no Sul do Brasil. Floresta, v.43, p.39-48, 2013. DOI: https://doi.org/10.5380/rf.v43i1.28680.

MARUSHIA, R.G.; ALLEN, E.B. Control of exotic annual grasses to restore native forbs in abandoned agricultural land. Restoration Ecology, v.19, p.45-54, 2011. DOI: https://doi.org/10.1111/j.1526-100X.2009.00540.x.

MAZA-VILLALOBOS, S.; BALVANERA, P.; MARTÍNEZRAMOS, M. Early regeneration of tropical dry forest from abandoned pastures: contrasting chronosequence and dynamic approaches. Biotropica, v.43, p.666-675, 2011. DOI: https://doi.org/10.1111/j.1744-7429.2011.00755.x.

MEDEIROS, A.C.; VON ALLMEN, E.I.; CHIMERA, C.G. Dry forest restoration and unassisted native tree seedling recruitment at Auwahi, Maui. Pacific Science, v.68, p.33-45, 2014. DOI: https://doi.org/10.2984/68.1.3.

PEREIRA, G.R.; ZOBIOLE, L.H.S.; SANTI ROSSI, C.V. Resposta no controle de capim-amargoso a mistura de tanque de glyphosate e haloxifope com auxinas sínteticas. Revista Brasileira de Herbicidas, v.17, e606, 2018. DOI: https://doi.org/10.7824/rbh.v17i2.606.

PIAIA, B.B.; ROVEDDER, A.P.M.; STEFANELLO, M. de M.; FELKER, R.M.; PIAZZA, E.M. Análise do banco de sementes visando estratégia de transposição para a restauração ecológica no Rio Grande do Sul. Floresta, v.47, p.221-228, 2017. DOI: https://doi.org/10.5380/rf.v47i1.46842.

PIJL, L. VAN DER. Principles of dispersal in higher plants. $3^{\text {nd }}$ ed. Berlin: Springer-Verlag, 1982. DOI: https://doi.org/10.1007/978-3-642-87925-8.

REIS, A.; BECHARA, F.C.; TRES, D.R.; TRENTIN, B.E. Nucleação: concepção biocêntrica para a restauração ecológica. Ciência Florestal, v.24, p.509-519, 2014. DOI: https://doi.org/10.5902/1980509814591.

SANTOS, H.G. dos; JACOMINE, P.K.T.; ANJOS, L.H.C. dos; OLIVEIRA, V.Á. de; LUMBRERAS, J.F.; COELHO, M.R.; ALMEIDA, J.A. de; ARAÚJO FILHO, J.C. de; OLIVEIRA, J.B. de; CUNHA, T.J.F. Sistema brasileiro de classificação de solos. 5.ed. rev. e ampl. Brasília: Embrapa, 2018. 356p. 
SCHEER, M.B.; GATTI, G.; WISNIEWSKI, C. Nutrient fluxes in litterfall of a secondary successional alluvial rain forest in Southern Brazil. Revista de Biologia Tropical, v.59, p.18691882, 2011.

SIMBERLOFF, D. Biological invasions: what's worth fighting and what can be won? Ecological Engineering, v.65, p.112-121, 2014. DOI: https://doi.org/10.1016/j.ecoleng.2013.08.004.

SOBANSKI, N.; MARQUES, M.C.M. Effects of soil characteristics and exotic grass cover on the forest restoration of the Atlantic Forest region. Journal for Nature Conservation, v.22, p.217-222, 2014. DOI: https://doi.org/10.1016/j.jnc.2014.01.001.

TOMAZI, A.L.; CASTELLANI, T.T. Artificial perches and solarization for forest restoration: assessment of their value. Tropical Conservation Science, v.9, p.809-831, 2016. DOI: https://oi.org/10.1177/194008291600900215.
VOGEL, H.F.; CAMPOS, J.B.; BECHARA, F.C. Early bird assemblages under different subtropical forest restoration strategies in Brazil: passive, nucleation and high diversity plantation. Tropical Conservation Science, v.8, p.912-939, 2015. DOI: https://doi.org/10.1177/194008291500800404.

WEIDLICH, E.W.A.; FLÓRIDO, F.G.; SORRINI, T.B.; BRANCALION, P.H.S. Controlling invasive plant species in ecological restoration: a global review. Journal of Applied Ecology, v.57, p.1806-1817, 2020. DOI: https://doi.org/10.1111/1365-2664.13656.

ZAHAWI, R.A.; HOLL, K.D.; COLE, R.J.; REID, J.L. Testing applied nucleation as a strategy to facilitate tropical forest recovery. Journal of Applied Ecology, v.50, p.88-96, 2013. DOI: https://doi.org/10.1111/1365-2664.12014. 